\title{
Antimicrobial activity of different plants extracts against Staphylococcus aureus and Escherichia coli
}

\author{
Mohd Imran ${ }^{1, B}$, Aiysha Siddiq Khan ${ }^{2, B}$, Mohammad Ali Khan ${ }^{2, C}$, \\ Mohammad Umar Saeed ${ }^{2, B, E}$, Naima Noor ${ }^{2, C}$, Musarrat Husain Warsi ${ }^{3, E}$, Abdul Qadir ${ }^{4, A, F}$ \\ 1 Department of Pharmacognosy and Phytochemistry, School of Pharmaceutical Education and Research, New Delhi, India \\ ${ }^{2}$ Clinical Biochemistry Lab, Department of Biochemistry, School of Chemical and Life Science, New Delhi, India \\ ${ }^{3}$ Department of Pharmaceutics and Industrial Pharmacy, College of Pharmacy, Taif University, Saudi Arabia \\ ${ }^{4}$ Herbalfarm Lifecare Pvt. Ltd., New Delhi, India
}

A - research concept and design; $\mathrm{B}$ - collection and/or assembly of data; $\mathrm{C}$ - data analysis and interpretation;

$D$ - writing the article; $E$ - critical revision of the article; $F$ - final approval of the article

Polymers in Medicine, ISSN 0370-0747 (print), ISSN 2451-2699 (online)

Polim Med. 2021;51(2):69-75

\section{Address for correspondence \\ Abdul Qadir}

E-mail:aqkhan90@gmail.com

\section{Funding sources}

None declared

\section{Conflict of interest}

None declared

\section{Acknowledgements}

The authors would like to sincerely thank

Jamia Hamdard (deemed to be university),

New Delhi, India, for providing necessary

facilities for this research work.

Received on August 12, 2021

Reviewed on October 28, 2021

Accepted on 0ctober 28, 2021

Published online on November 16, 2021

Cite as

Imran M, Khan AS, Khan MA, et al. Antimicrobial activity

of different plants extracts against Staphylococcus aureus and

Escherichia coli. Polim Med. 2021;51(2):69-75.

doi:10.17219/pim/143424

DOI

10.17219/pim/143424

Copyright

○ 2021 by Wroclaw Medical University

This is an article distributed under the terms of the

Creative Commons Attribution 3.0 Unported (CC BY 3.0)

(https://creativecommons.org/licenses/by/3.0/)

\begin{abstract}
Background. Microbial pathogens, mainly bacteria, are a major cause of food spoilage resulting in several foodborne diseases. Food spoilage can be prevented by the application of chemical preservatives in the food industry but such process has harmful effects on human health and causes the introduction of chemicals in several food chains, leading to toxicity and long-term complications. Due to such adverse effects, the need to find natural preservatives that are safer to use, effective and less complicated is increasing.

Objectives. This study is based on plant extracts that play a major role in microbicidal action (the use of natural preservatives is preferred over chemical ones). Antimicrobial action of different plant extracts was assessed using Staphylococcus aureus and Escherichia coli as experimental bacterial strains.

Material and methods. Ethanolic extracts of different plants like Punica granatum, Acacia catechu and Phyllanthus emblica were highly effective against the both analyzed bacterial strains at a dosage of $10 \mathrm{mg} / \mathrm{mL}$, while the extracts of Ocimum bacilicum and Quercus infectoria were effective only against $S$. aureus and E. coli, respectively.
\end{abstract}

Results. Punica granatum and Phyllanthus emblica extracts were found to be the most effective and exhibited bacteriostatic and bactericidal activities against the highly infectious strains of pathogenic bacteria causing food spoilage, with minimum inhibitory concentration (MIC) of $2.5 \mathrm{mg} / \mathrm{mL}$ and minimum bactericidal concentration (MBC) of $5 \mathrm{mg} / \mathrm{mL}$.

Conclusions. The plant extracts used in the study were highly effective in reducing bacterial contamination and can be used as an alternative to chemical preservatives to avoid and control foodborne diseases and for preservation of food with no health-related hazards caused by chemicals.

Key words: Escherichia coli, Staphylococcus aureus, antimicrobial activity, plant extract 


\section{Background}

There are over 1.8 million deaths worldwide per annum, mostly in young children, due to contaminated edibles, including water. According to the data of the World Health Organization (WHO), 76 million cases of foodborne diseases are recorded worldwide annually, with approx. 5000 deaths. Ingesting nutrition which has been compromised by bacteria, protozoa, toxins, and other contaminants seems to be the most prevalent source of infection and sickness. It is one of the leading causes of illness as well as mortality in poor nations. Bacteriological pollutants, primarily Gram-negative bacteria such as Escherichia coli, Pseudomonas aeruginosa and Salmonella typhi, are perhaps the most pronounced risk to public health., ${ }^{1,2}$

Certain bacterial species, such as Bacillus cereus and Staphylococcus aureus, have indeed been linked to local foodstuff spoilage. ${ }^{2}$ Anti-targets have been continuously used in product packaging to prevent the decay of packaged foods. ${ }^{2,3}$ Emphasis has been put on healthy, effective and natural food preservatives. ${ }^{4}$

Toxic substances of this kind have proven their efficiency in identifying and mitigating nosocomial infections, but their widespread use has contributed to the establishment of such hazardous substances in food chains, along with a whole slew of adverse environmental effects. Biocompatible chemicals are utilized as organic compounds against pathogenic microorganisms because they are both harmless and edible. ${ }^{1,6}$

Several researches have demonstrated the bioactivity of phytochemicals against disease-causing microorganisms. ${ }^{7}$ The antibacterial efficacy of garlic, ginger and guava foliage against a diversity of social infectious agents had been studied, and it was discovered that ginger was perhaps the most efficient towards $S$. aureus, while guava and garlic proved efficacious against most of the microbes studied. ${ }^{8}$ Antibacterial property towards B. subtilis and B. cereus was previously discovered in the foliage of Syzygium polyanthum. ${ }^{9}$

Pseudomonas aeruginosa and Bacillus subtilis have also been examined, and it was found that perhaps the ethanolic extracts of 4 plants (Achyranthes aspera, Cynodon dacynodon dactylon, Lantana camara, and Tagetes patula) are effective against most of the bacterial isolates, with minimum inhibitory concentration (MIC) ranging between $25 \mathrm{mg} / \mathrm{mL}$ and $125 \mathrm{mg} / \mathrm{mL} .{ }^{10}$

The water-soluble extractions of cinnamon, aloe vera, henna, coriander, myrtle, and chamomile, as well as the hydro-alcoholic extractions of menthol, henna, ginger, chamomile, olive, myrtle, and Christ's thorn, act as their populations grow in small increments in their inhibition zones of approx. 10-28 mm.

Aquil and Ahmad discovered that ethanolic garlic extracts had almost no antibacterial activity against $E$. coli or Shigella dysenteriae, Shigella flexneri, Shigella boydii, and Shigella sonnei. ${ }^{12}$ In the research by Akinpelu et al., strong antimicrobial effectiveness of butanolic and pure isolates of Persea americana infected with B. cereus in foodborne illnesses was observed. ${ }^{13}$ The minimum bactericidal concentration (MBC) of extracts varied between $3.12 \mathrm{mg} / \mathrm{mL}$ and $12.5 \mathrm{mg} / \mathrm{mL}$, and these isolates showed antibacterial activity at doses of $25 \mathrm{mg} / \mathrm{mL}$ and $10 \mathrm{mg} / \mathrm{mL}$. Likewise, several of these phytoconstituents have already been tested for antimicrobial effect toward microbial nutrition substances required by the organism to obtain nutrition by catabolism and anabolism. ${ }^{14} \mathrm{Nu}$ merous therapeutic medicinal plants have been shown to counteract foodstuff-related illnesses.

Three therapeutic phytoconstituents utilized in Nigerian traditional system of medicine were shown to have high antimicrobial activity against a broad range of foodborne infections. All had a strong antibacterial effect towards S. aureus, E. coli and Salmonella enteritidis, albeit to a varying extent and often with varying MICs depending on the used plant compounds and microorganisms. ${ }^{15}$

Mikania triangularis, often characterized as "leaf guaco", exhibits antibacterial properties against 5 fungal isolates, 3 bacterium species, as well as Staphylococcus epidermidis, $S$. aureus, B. cereus, and $P$. aeruginosa, among others. ${ }^{16}$ Investigators have also studied the antibacterial efficacy of 8 natural herb isolates against Listeria monocytogenes, B. cereus and E. coli. ${ }^{17}$ Methanolic extracts of Caryophyllus aromaticus were shown to have the highest antimicrobial effect over S. aureus and had been significant against those same microorganisms. ${ }^{18}$

Bioactive compounds from Myrtus communis and Thymus daenensis are perhaps the most effective, with MIC coefficients ranging from $0.039 \mathrm{mg} / \mathrm{mL}$ to $10 \mathrm{mg} / \mathrm{mL}$. Many researchers have investigated and validated the antibacterial effectiveness of Punica granatum against germs that cause food spoilage. ${ }^{19}$

Verma et al. computed the antimicrobial properties of tested compounds inhospitable to nutrition pathogenic organisms, including the Citrus, Punica, as well as Allium plant extracts. ${ }^{20}$ Thus, every crude extract tested was intrinsically efficacious against different organism like $S$. aureus, B. cereus, S. typhi, and E. coli; however, the Punica granatum isolates showed genuinely highest potency with a concentration over $500 \mathrm{mg} / \mathrm{mL}$. Within a concentration between $30 \mathrm{mg} / \mathrm{mL}$ and $50 \mathrm{mg} / \mathrm{mL}$, Punica granatum peeling ethanolic extracts have been shown to be efficacious towards Bacillus megaterium, S. aureus, Micrococcus luteus, and Gram-negative bacteria such as E. coli and P. aeruginosa. ${ }^{21}$

Because of the strong antimicrobial properties of Punica granatum ethanolic extracts as well as their chunk toward Gram-negative (E. coli and S. typhi) and Gram-positive bacteria (S. aureus and B. cereus) causing foodborne illnesses, those certain extracts are used as stabilizing agents in the food processing industry to protect consumers against foodborne diseases. ${ }^{22}$ 
Several spice formulations used in nutritional supplements are highly effective toward numerous food contamination microorganisms; their antimicrobial effects have been shown by many researchers. ${ }^{23}$ For example, cinnamon isolates were shown to be an excellent antimicrobial agent against all tested bacterial strains; ginger, clove and cumin are more effective than cinnamon extracts. Cloves have been found to have antimicrobial properties against Gram-negative bacteria and other diseases. ${ }^{1,4,24}$

According to numerous studies, ethanolic cloves infusion may indeed be helpful against $S$. aureus, Vibrio parahaemolyticus and $P$. aeruginosa, but inadequate against E. coli and S. enteritidis. ${ }^{25}$ Clove oil has been shown to be effective against all dangerous microorganisms assessed in several investigations, with perhaps the exception of Vibrio cholerae, Klebsiella pneumoniae and S. typhi, that also have been shown to be impervious to diluted clove extract. ${ }^{26}$

Furthermore, the methanolic extracts of cloves are claimed to be efficacious towards $S$. aureus, $P$. aeruginosa and $E$. coli, with MIC values ranging from $0.1 \mathrm{mg} / \mathrm{mL}$ to $2.31 \mathrm{mg} / \mathrm{mL} .{ }^{27}$ Cumin seeds (Cuminum cyminum) aqueous extract has been shown to have antimicrobial effect against some of the Gram-positive and Gram-negative bacteria, exhibiting varying MIC. . $^{3,2}$

Cumin extract has been shown to be efficacious towards E. coli, P. aeruginosa, S. aureus, and Bacillus pumilus, with MIC values ranging between $6.25 \mathrm{mg} / \mathrm{mL}$ and $25 \mathrm{mg} / \mathrm{mL},{ }^{29}$ and prescribed dosages ranging from $20 \mathrm{mg} / \mathrm{mL}$ to $60 \mathrm{mg} / \mathrm{mL}^{30}$

The effectiveness of 7 ethanolic and aqueous plant extracts was evaluated against several clinically dangerous bacteria. The ethanol extract of Punica granatum was shown to be efficacious against all pathogenic microorganisms assayed, with a MIC value of $0.2 \mathrm{mg} / \mathrm{mL}$. Thymus kotschyana extract was shown to be efficacious towards E. coli and S. aureus; however, Zingiber officinalis isolate was shown to counteract $P$. aeruginosa and K. pneumoniae. ${ }^{31}$

Numerous thyme bioactive compounds have been tested for their bactericidal effectiveness against foodborne infections (L. monocytogenes). The prevalence of foodborne diseases have indeed been linked to dangerous microorganisms, notably Gram-negative bacteria like E. coli, S. typhi and $P$. aeruginosa, and other Gram-positive pathogens like $S$. aureus and B. cereus. There is a scarcity of studies in the Arabian region on the viability of Syzygium aromaticum, Thymus vulgaris, Punica granatum, Zingiber officinale, and Cuminum cyminum against many of the previously mentioned pathophysiological food decomposing bacteria. Therapeutic properties of many bioactive compounds against diseases caused by S. aureus, B. cereus, E. coli, S. typhi, and $P$. aeruginosa are now being evaluated in vitro.

\section{Material and methods}

\section{Performing the Soxhlet method of alcoholic extraction}

Material (galls, peels, heartwood, fruit, and whole plants) from 5 different plant species (Table 1) were obtained from the Universal Biotech Khari Baoli (Old Delhi, India). Plant parts were washed many times to remove any possible impurities. After drying, each plant material was crushed into fine powder that passed through a $100 \mathrm{~mm}$ sieve. Approximately $10 \mathrm{~g}$ of fine powder was immersed in $100 \mathrm{~mL}$ of ethanol and extracted for $48 \mathrm{~h}$ with continuous stirring, and then filtered with two-layer muslin cloth, centrifuged for $10 \mathrm{~min}$ at $9000 \mathrm{rpm}$, and finally filtered again using Whatman filter paper (41; Merck Millipore, Mumbai, India). The filtrates were dried using a rotary vacuum evaporator (Hahnshin Scientific, Mumbai, India) under reduced pressure at $60^{\circ} \mathrm{C}$ and stored in the refrigerator at $5^{\circ} \mathrm{C}$. The percentage of yields was measured using the following formula ${ }^{32}$ :

$$
\text { yields of extract }(\% \mathrm{w} / \mathrm{w})=\mathrm{R} / \mathrm{S} \times 100
$$

where $\mathrm{R}$ - plant residues extracted weight and S - raw sample of plant weight.

\section{Antibacterial activity of the plant extracts}

\section{Bacterial strains}

Two strains of bacteria that cause food poisoning were used to test the antibacterial effectiveness of extract of each plant species. In this experiment, we used 1 strain of Gram-positive bacteria (S. aureus) and 1 strain of Gramnegative bacteria (E. coli). The strains were collected from the Biochemistry Department of Jamia Hamdard (deemed to be university), New Delhi, India.

Table 1. Ethnobotanical data of examined plant species and their extract yield percentage

\begin{tabular}{|l|c|c|c|c|c|c|}
\multicolumn{1}{|c|}{ Plant species } & Family & Local name & Common name & Plant part used & Extract pH & $\begin{array}{c}\text { Extract } \\
\text { yield }\end{array}$ \\
\hline Quercus infectoria & Fagaceae & manjakani & Aleppo oak & galls & 4.8 & $1.2 \%$ \\
Punica granatum & Lythraceae & romman & pomegranate & peels & 4.5 & $2.3 \%$ \\
Acacia catechu & Fagaceae & khair & black cutch & heart wood & 7.2 & $2.1 \%$ \\
Ocimum basilicum & Lamiaceae & tulsi & basil & whole plant & 7.8 & $1.98 \%$ \\
Phyllanthus emblica & Phyllanthaceae & amla & Indian gooseberry & fruits & 3.9 & $2.4 \%$ \\
\hline
\end{tabular}




\section{Inoculum preparation}

Both strains of bacteria were left overnight for culture in Mueller-Hinton agar medium at $35^{\circ} \mathrm{C}$. Using a spectrophotometer, the growth of bacteria was harvested in $5 \mathrm{~mL}$ of sterile saline water, and the cell count was diluted to $10^{7} \mathrm{CFU} / \mathrm{mL}$ at $580 \mathrm{~nm}$.

\section{Antibacterial activity of plants extract}

The antibacterial activity of each plant extract was estimated using the disc diffusion method. The residues of plant extract $(50 \mathrm{mg})$ were re-dissolved in $2.5 \mathrm{~mL}$ of ethanol. After that, purification was performed with a Millipore filter $(0.22 \mathrm{~mm}$; Merck Millipore) and then loaded over a sterile disc of filter paper to reach a final concentration of $10 \mathrm{mg} / \mathrm{disc}$. Then, $15 \mathrm{~mL}$ of seeded medium previously infected with bacterial suspension (100 mL of medium $/ 1 \mathrm{~mL}$ of $10^{7} \mathrm{CFU}$ ) was added to $10 \mathrm{~mL}$ of Mueller-Hinton agar media in Petri dishes to achieve $10^{5} \mathrm{CFU} / \mathrm{mL}$ of media.

Sterile filter paper discs with extract of plant concentration $(10 \mathrm{mg} / \mathrm{mL})$ were inserted on top of the plates of Mueller-Hinton agar media in Petri dishes. Discs of filter paper containing $5 \mathrm{mg}$ of gentamicin as a positive control were utilized. After this, the plates were kept for $2 \mathrm{~h}$ in a fridge at $5^{\circ} \mathrm{C}$ to allow extract of plant to diffuse before being incubated for $24 \mathrm{~h}$ at $35^{\circ} \mathrm{C}$. The presence of inhibitory zones was measured using a Vernier caliper, recorded and interpreted as a marker of antibacterial activity.

\section{Determination of minimum inhibitory concentrations of the effective plant extract}

After $24 \mathrm{~h}$ of incubation, the MIC was characterized by a low concentration of antibacterial agents that prevent microbial growth. By using the method of disc diffusion, the most effective extracts of plants, having strong antimicrobial activities at $10 \mathrm{mg} / \mathrm{mL}$, were modified to calculate their MIC and examine their efficiency in reducing bacterial strains that cause food poisoning. By dissolving $50 \mathrm{mg}$ of plant extracts in $2.5 \mathrm{~mL}$ of ethanol, filtering it with a Millipore filter and transferring the required amount to sterile discs, effective plant extracts with different concentrations $(1.25 \mathrm{mg} / \mathrm{mL}, 2.5 \mathrm{mg} / \mathrm{mL}, 5 \mathrm{mg} / \mathrm{mL}, 10 \mathrm{mg} / \mathrm{mL}$, $12.5 \mathrm{mg} / \mathrm{mL}$, and $15 \mathrm{mg} / \mathrm{mL}$ ) were produced (the discs had $8 \mathrm{~mm}$ in diameter). Pathogenic strains of cultured bacteria were infused using Mueller-Hinton agar into sterile Petri dishes. Various amounts of extracts were obtained and loaded onto filter paper discs; Mueller-Hinton agar plates were later covered. The plates were then kept at $5^{\circ} \mathrm{C}$ in the fridge for $2 \mathrm{~h}$ and then incubated for $24 \mathrm{~h}$ at $35^{\circ} \mathrm{C}$. By the help of Vernier caliper inhibition zones were determined and compared to the concentration of the effective extract of the plant.
Determination of minimum bactericidal concentrations of the effective plants extract

Two streaks of plates bearing MIC inhibitory zones with little concentration were collected and cultivated in tryptone soya agar (TSA) plates that displayed limited growth. Next, the plates were put for incubation at $35^{\circ} \mathrm{C}$ for $24 \mathrm{~h}$. The growth of bacteria was observed in different plant extract concentrations. On freshly infected agar plates, $\mathrm{MBC}$ was defined as the extract of plant concentration that did not show any bacterial growth.

\section{Results and discussion}

\section{Plants extraction yield}

The data for the plants that have been used and their extract percentage yield are presented in Table 1 . Ten grams of dried powder plant material allowed for a yield of plant extract ranging from $198 \mathrm{mg}$ to $240 \mathrm{mg}$. The highest yield of plant extract was obtained from Phyllanthus emblica (240 mg) followed by Punica granatum (230 mg), while Quercus infectoria gave the lowest extract yield (120 mg).

\section{Antibacterial activity of plants extract}

To examine the antibacterial activity of plants against food poisoning bacteria, 5 plant species were assessed against a strain of Gram-negative bacteria (E. coli) and a strain of Gram-positive bacteria (S. aureus). Disc diffusion method was used for the assessment and to find the susceptibility of bacteria. Antibacterial action of plant extracts is presented in Table 2 and Fig. 1 . It was found that the used plant extracts were very effective in counteracting the bacterial growth that leads to food poisoning.

Punica granatum was found to be the most effective extract - it has reduced the growth of pathogenic bacteria (S. aureus and E. coli) at a concentration of $10 \mathrm{mg} / \mathrm{mL}$. Phyllanthus emblica was also found effective against both of the pathogenic strains. Varying antimicrobial activity

Table 2. Antimicrobial screening test of ethanolic plant extract $(10 \mathrm{mg} / \mathrm{mL})$ against some of the bacterial strains causing food poisoning

\begin{tabular}{|l|c|c|}
\hline \multirow{2}{*}{ Plant species } & \multicolumn{2}{|c|}{ Inhibition zones [mm] } \\
\cline { 2 - 3 } & $\begin{array}{c}\text { Gram-positive } \\
\text { pathogenic bacteria } \\
\text { (S. aureus) }\end{array}$ & $\begin{array}{c}\text { Gram-negative } \\
\text { pathogenic bacteria } \\
\text { (E. coli) }\end{array}$ \\
\hline Quercus infectoria & $8.6 \pm 0.67$ & $0.0 \pm 0.0$ \\
Punica granatum & $17.9 \pm 0.10$ & $14.4 \pm 0.53$ \\
Acacia catechu & $16.3 \pm 0.27$ & $13.1 \pm 0.27$ \\
Ocimum basilicum & $15.7 \pm 0.24$ & $0.0 \pm 0.0$ \\
Phyllanthus emblica & $16.5 \pm 0.32$ & $14.2 \pm 0.21$ \\
Gentamicin (5 $\mathrm{Mg})$ & $18.5 \pm 0.21$ & $14.9 \pm 0.49$ \\
\hline
\end{tabular}

Data are means of 3 replicates $(n=3) \pm$ standard error $(S E)$. 

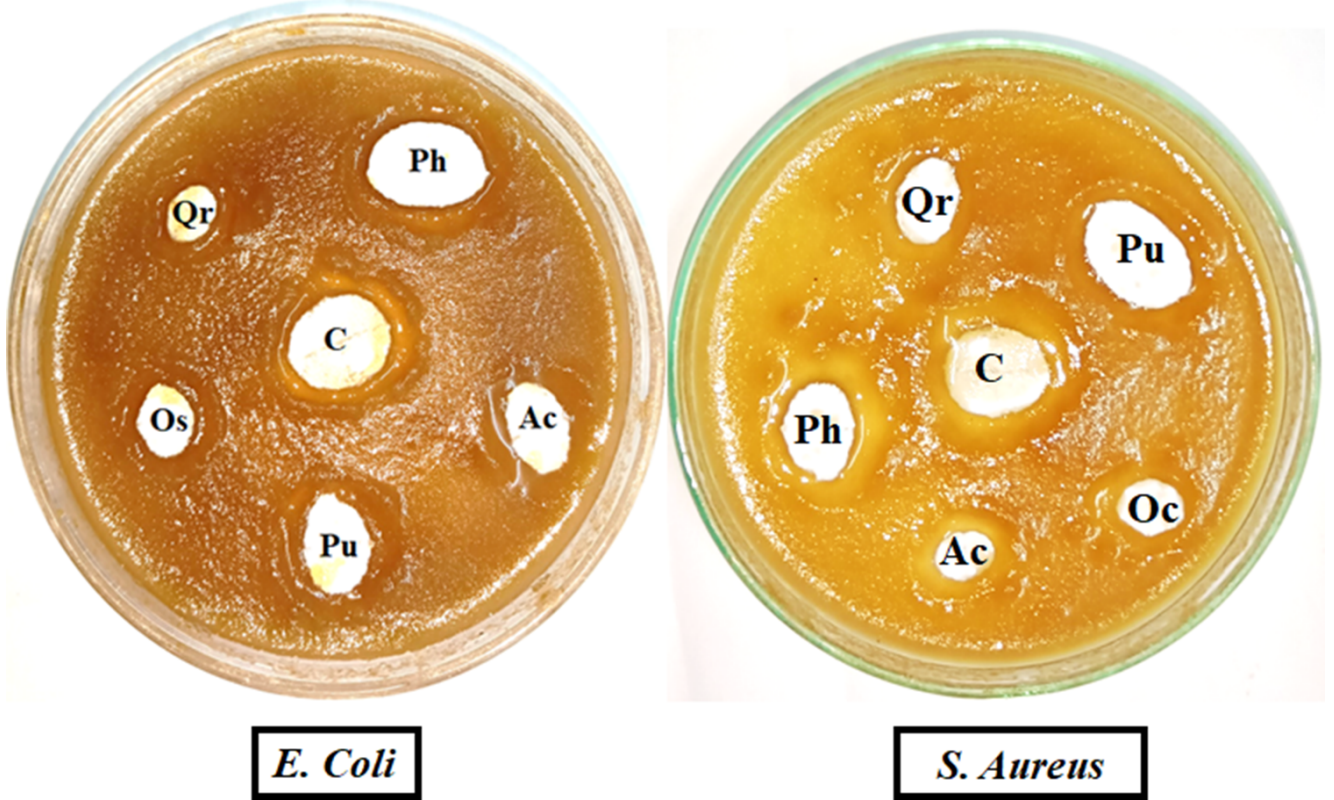

Fig. 1. Growth inhibition of bacterial strains caused by some plant extracts. Quercus infectoria (Qr), Punica granatum (Pu), Acacia catechu (Ac), Phyllanthus emblica (Ph), Ocimum bacilicum (Os), and C (positive control) was also shown by other plants against food poisoning bacterial strains. Acacia catechu was proved effective against both bacterial strains, while Ocimum bacilicum and Quercus infectoria only affected S. aureus and had a negligible effect on $E$. coli bacteria.

Antimicrobial action of the plant extracts indicates that $E$. coli was the strain most resistant to the used plant extracts. Punica granatum and Phyllanthus emblica extracts showed highly effective antibacterial action. The experiments were conducted to find the MIC and MBC values of the food poisoning bacteria (S. aureus and E. coli).

\section{Minimum inhibitory concentration of the effective plants extract}

The MIC values of the effective plant extracts (Punica granatum and Phyllanthus emblica) were calculated using disc diffusion method to find out the bacteriostatic and bactericidal properties of the plant extracts. The concentration of the plant extracts which were found effective are presented in Table 3. The inhibiting effect of $P u$ nica granatum extract was detected at a concentration of $2.5 \mathrm{mg} / \mathrm{mL}$, with the zone of inhibition at $9.5 \mathrm{~mm}$ and $7.5 \mathrm{~mm}$ for $S$. aureus and $E$. coli, respectively, while the extract of Phyllanthus emblica reduced the growth of bacteria at concentration of $2.5 \mathrm{mg} / \mathrm{mL}$, forming a small inhibition zone of $8.7 \mathrm{~mm}$ and $5.6 \mathrm{~mm}$ for $S$. aureus and E. coli, respectively.

\section{Minimum bactericidal concentrations of the effective plants extract}

The MBC can be identified by the absence of bacterial growth streaked from the inhibition zone correlating to the tested strains' lowest MIC. Punica granatum was found to have an effective bactericidal activity against
Table 3. Minimum inhibitory concentrations (MICs) of the most effective plant extract against S. aureus and E. coli

\begin{tabular}{|c|c|c|c|}
\hline \multirow[b]{2}{*}{$\begin{array}{l}\text { Plant } \\
\text { extract }\end{array}$} & \multirow[b]{2}{*}{$\begin{array}{l}\text { Concen- } \\
\text { tration } \\
{[\mathrm{mg} / \mathrm{mL}]}\end{array}$} & \multicolumn{2}{|c|}{ Inhibition zones [mm] } \\
\hline & & $\begin{array}{c}\text { Gram-positive } \\
\text { pathogenic } \\
\text { bacteria (S. aureus) }\end{array}$ & $\begin{array}{c}\text { Gram-negative } \\
\text { pathogenic } \\
\text { bacteria }(E . \text { coli) }\end{array}$ \\
\hline \multirow{6}{*}{$\begin{array}{l}\text { Punica } \\
\text { granatum }\end{array}$} & 1.25 & $0.0 \pm 0.0$ & $0.0 \pm 0.0$ \\
\hline & 2.50 & $9.5 \pm 0.60$ & $7.5 \pm 0.13$ \\
\hline & 5.0 & $13.7 \pm 0.77$ & $10.3 \pm 0.21$ \\
\hline & 10.0 & $17.2 \pm 0.69$ & $13.7 \pm 0.27$ \\
\hline & 12.5 & $20.7 \pm 0.32$ & $16.9 \pm 0.52$ \\
\hline & 15.0 & $23.4 \pm 0.27$ & $19.7 \pm 0.61$ \\
\hline \multirow{6}{*}{$\begin{array}{l}\text { Phyllanthus } \\
\text { emblica }\end{array}$} & 1.25 & $0.0 \pm 0.0$ & $0.0 \pm 0.0$ \\
\hline & 2.50 & $8.7 \pm 0.21$ & $5.6 \pm 0.19$ \\
\hline & 5.0 & $12.3 \pm 0.31$ & $9.7 \pm 0.21$ \\
\hline & 10.0 & $14.9 \pm 0.41$ & $13.4 \pm 0.33$ \\
\hline & 12.5 & $17.2 \pm 0.56$ & $16.3 \pm 0.41$ \\
\hline & 15.0 & $19.4 \pm 0.69$ & $18.2 \pm 0.52$ \\
\hline
\end{tabular}

$S$. aureus and E. coli, having a $\mathrm{MBC}$ value of $5 \mathrm{mg} / \mathrm{mL}$, while Phyllanthus emblica extract also had an MBC value of $5 \mathrm{mg} / \mathrm{mL}$. Based on that, it can be suggested that Punica granatum and Phyllanthus emblica can be used to counteract foodborne pathogens and diseases. Bacteria used in this study play a major role in food decomposition and food poisoning. Staphylococcus aureus is regarded one of the most common causes of foodborne diseases, while $E$. coli is responsible for producing harmful toxins and other components that play an important role in human gastrointestinal diseases. Punica granatum was found effective in inhibiting the growth of all bacterial strains, while Phyllanthus emblica extract was found highly effective against $S$. aureus and less effective against $E$. coli. ${ }^{33}$ Due to differences in method used for extraction, as well 
as in components and bacterial strains used in the experiment, a significant variability in MIC of Punica granatum could be observed in comparison to other investigations, leading to variation in MIC of different plants extracts. Variations can also be caused by the properties of the chemicals like volatility and the disparities between the chemical constituents. Phyllanthus emblica extract was found to be effective with a $10 \mathrm{mg} / \mathrm{mL}$ concentration against $S$. aureus and $E$. coli, inhibiting their growth and forming the inhibition zones of $14.9 \mathrm{~mm}$ and $13.4 \mathrm{~mm}$, respectively. ${ }^{34}$ Some researchers, after studying the plant extracts and their effect on certain bacteria, suggested that plants components like terpenoids, alkaloids and phenolic compounds react with components of bacterial cell membrane and proteins present on it, causing their lysis by inducing an efflux of proton outside the cell or inhibiting important enzymes responsible for synthesis of amino acids. ${ }^{35}$ Other study accredited the effect of plant extracts to their hydrophobic properties, which cause the reaction of protein in bacterial cell membrane with mitochondria, leading to lysis and alteration of bacterial structure, and changing its permeability. ${ }^{36}$ This study suggests that plant extracts used in this experiment have shown effective antibacterial properties and can also be used as natural preservatives, thereby reducing the application of chemically made preservatives in food industry, which leads to several health hazards.

\section{Conclusions}

Various harmful bacteria strains can cause food spoilage. It can be prevented by the application of chemical preservatives in the food industry, but such means have harmful effects on human health and cause the introduction of chemicals in several food chains, leading to toxicity and long-term complications. Due to such adverse effects, natural preservatives that are safer to use, effective and less complicated have to be developed. Existing plant extracts which have shown their potential usefulness $(P u$ nica granatum and Phyllanthus emblica) can be employed as a natural alternative to synthetic antimicrobial agents to prevent food poisoning.

\section{ORCID iDs}

Mohd Imran (1) https://orcid.org/0000-0001-7349-3019 Aiysha Siddiq Khan (1) https://orcid.org/0000-0002-7691-9844 Mohammad Ali Khan (1) https://orcid.org/0000-0001-7694-6423 Mohammad Umar Saeed (1) https://orcid.org/0000-0002-2052-5934 Naima Noor (1) https://orcid.org/0000-0002-2937-4239 Musarrat Husain Warsi (1) https://orcid.org/0000-0002-9071-8889 Abdul Qadir (1) https://orcid.org/0000-0002-7119-0847

\section{References}

1. Solomakos N, Govaris A, Koidis P, Botsoglou N. The antimicrobial effect of thyme essential oil, nisin and their combination against Escherichia coli 0157: $\mathrm{H7}$ in minced beef during refrigerated storage. Meat Sci. 2008;80(2):159-166. doi:10.1016/j.meatsci.2007.11.014
2. Pandey A, Singh P. Antibacterial activity of Syzygium aromaticum (Clove) with metal ion effect against food borne pathogens. Asian J Plant Sci Res. 2011;1(2):69-80. https://www.imedpub.com/articles/ antibacterial-activity-of-syzygium-aromaticum-clove-with-metalion-effect-against-food-borne-pathogens.pdf

3. Braga LC, Shupp JW, Cummings C, Jett M, Takahashi JA, Carmo LS. Pomegranate extract inhibits Staphylococcus aureus growth and subsequent enterotoxin production. J Ethnopharmacol. 2005;96(1-2): 335-339. doi:10.1016/j.jep.2004.08.034

4. Yamamura A, Murai A, Takamatsu H, Watabe K. Antimicrobial effect of chemical preservatives on enterohemorrhagic Escherichia coli O157: H7. J Health Sci. 2000;46(3):204-208. doi:10.1248/jhs.46.204

5. Shan B, Cai Y, Brooks JD, Corke H. The in vitro antibacterial activity of dietary spice and medicinal herb extracts. Int J Food Microbiol. 2007;117(1):112-119. doi:10.1016/j.ijfoodmicro.2007.03.003

6. Duffy CF, Power RF. Antioxidant and antimicrobial properties of some Chinese plant extracts. Int J Antimicrob Agents. 2001;17(6):527-529. doi:10.1016/s0924-8579(01)00326-0

7. Bialonska D, Ramnani P, Kasimsetty SG, Muntha KR, Gibson GR, Ferreira $D$. The influence of pomegranate by-product and punicalagins on selected groups of human intestinal microbiota. Int J Food Microbiol. 2010;140(2-3):175-182. doi:10.1016/j.ijfoodmicro.2010.03.038

8. Nasar-Abbas SM, Kadir Halkman A. Antimicrobial effect of water extract of sumac (Rhus coriaria $\mathrm{L}$.) on the growth of some food borne bacteria including pathogens. Int J Food Microbiol. 2004;97(1):63-69. doi:10.1016/j.ijfoodmicro.2004.04.009

9. Hara-Kudo Y, Kobayashi A, Sugita-Konishi Y, Kondo K. Antibacterial activity of plants used in cooking for aroma and taste. J Food Prot. 2004;67(12):2820-2824. doi:10.4315/0362-028x-67.12.2820

10. Mathabe MC, Nikolova RV, Lall N, Nyazema NZ. Antibacterial activities of medicinal plants used for the treatment of diarrhea in Limpopo Province, South Africa. J Ethnopharmacol. 2005;105(1-2):286-293. doi:10.1016/j.jep.2006.01.029

11. Cowan MM. Plant products as antimicrobial agents. Clin Microbiol Rev. 1999;12(4):564-582. doi:10.1128/CMR.12.4.564

12. Aqil F, Ahmad I. Broad-spectrum antibacterial and antifungal properties of certain traditionally used Indian medicinal plants. World J Microbiol Biotech. 2003;19:653-657. https://doi.org/10.1023/A: 1025128104056

13. Akinpelu DA, Aiyegoro OA, Akinpelu OF, Okah Al. Stem bark extract and fraction of Persea americana (Mill) exhibits bactericidal activities against strains of Bacillus cereus associated with food poisoning. Molecules. 2015;20(1):416-429. doi:10.3390/molecules20010416

14. Chika CO, Jude NO, Ifeanyi CO, Anyanwu NB. Antibacterial activities and toxicological potentials of crude ethanolic extracts of Euphorbia hirta. J Am Sci. 2007;3(3):11-16. http://citeseerx.ist.psu.edu/viewdoc/ download?doi=10.1.1.626.7333\&rep=rep1\&type $=$ pdf

15. Delgado B, Palop A, Fernandez PS, Periago PM. Combined effect of thymol and cymene to control the growth of Bacillus cereus vegetative cells. Eur Food Res Technol. 2004;218(2):188-193. doi:10.1007/ s00217-003-0806-0

16. Alzoreky NS, Nakahara K. Antibacterial activity of extracts from some edible plants commonly consumed in Asia. Int J Food Microbiol. 2003;80(3):223-230. doi:10.1016/s0168-1605(02)00169-1

17. Sapkota R, Dasgupta R, Nancy, Rawat DS. Antibacterial effects of plants extract on human microbial pathogens \& microbial limit tests. Int J Res Pharm Chem. 2012;2(4):926-936. http://www.ijrpc.com/files/ 05-2154.pdf

18. Khan SU, Anjum SI, Ansari MJ, et al. Antimicrobial potentials of medicinal plant's extract and their derived silver nanoparticles: A focus on honey bee pathogen. Saudi J Biol Sci. 2019;26(7):1815-1834. doi:10. 1016/j.sjbs.2018.02.010

19. Narayan GR, Viswas K, Pathak M, Singh PS, Gupta A. Antibacterial activities of ethanolic extracts of plants used in folk medicine. International Journal of Research in Ayurveda and Pharmacy (IJRAP). 2010; 1(2):529-535.

20. Verma V, Singh R, Tiwari RK, Srivastava N, Verma S. Antibacterial activity of extracts of Citrus, Allium and Punica against food borne spoilage. Asian J Plant Sci Res. 2012;2(4):503-509. https://www.doc-developpement-durable.org/file/Culture/Culture-plantes-alimentaires/ FICHES_PLANTES/ail-oignon-echalotte/Antibacterial\%20activity\% 20of\%20extracts $\% 20$ of $\% 20$ Citrus, $\% 20$ Allium $\% 20 \& \% 20$ Punica $\% 20$ against $\% 20$ food\%20borne\%20spoilage.pdf 
21. Friedman M, Henika PR, Levin CE, Mandrell RE. Antibacterial activities of plant essential oils and their components against Escherichia coli 0157:H7 and Salmonella enterica in apple juice. J Agric Food Chem. 2004;52(19):6042-6048. doi:10.1021/jf0495340

22. Ahmad I, Beg AZ. Antimicrobial and photochemical studies on 45 Indian medicinal plants against multi-drug resistant human pathogens. J Ethnopharmacol. 2001;74(2):113-123. doi:10.1016/s0378-8741(00)00335-4

23. Kokoska L, Polesny Z, Rada V, Nepovim A, Vanek T. Screening of some Siberian medicinal plants for antimicrobial activity. J Ethnopharmacol. 2002;82(1):51-53. doi:10.1016/s0378-8741(02)00143-5

24. Ateş DA, Erdoğrul ÖT. Antimicrobial activities of various medicinal and commercial plant extracts. Turk J Biol. 2003;27(3-4):157-162. https://citeseerx.ist.psu.edu/viewdoc/download?doi=10.1.1.545.68 25\&rep=rep1\&type $=$ pdf

25. Rios JL, Recio MC. Medicinal plants and antimicrobial activity. J Eth nopharmacol. 2005;100(1-2):80-84. doi:10.1016/j.jep.2005.04.025

26. Ahmad I, Mehmood Z, Mohammad F. Screening of some Indian medicinal plants for their antimicrobial properties. J Ethnopharmacol. 1998;62(2):183-193. doi:10.1016/s0378-8741(98)00055-5

27. Akinyemi KO, Oluwa OK, Omogbehin EO. Antimicrobial activity of crude extracts of three medicinal plants used in south-west Nigerian folk medicine on some food borne bacterial pathogens. African J Trad Complement Altern Med. 2006;3(4):13-22. http://www.bioline. org.br/pdf?tc06048

28. Sher A. Antimicrobial activity of natural products from medicinal plants. Gomal J Med Sci. 2009;7(1):72-78. vlibrary.emro.who.int/ imemr/antimicrobial-activity-of-natural-products-from-medicinalplants-2/. Accessed November 4, 2021.
29. Venkatesan D, Karrunakaran CM. Antimicrobial activity of selected Indian medicinal plants. J Phytol. 2010;2(2):44-48. https://updatepublishing.com/journal/index.php/jp/article/view/2086. Accessed November 4, 2021.

30. Pirbalouti AG, Jahanbazi P, Enteshari S, Malekpoor F, Hamedi B. Antimicrobial activity of some Iranian medicinal plants. Arch Biol Sci. 2010;62(3):633-642. doi:10.2298/ABS1003633G

31. Prashanth DJ, Asha MK, Amit A. Antibacterial activity of Punica granatum. Fitoterapia. 2001;72(2):171-173. doi:10.1016/s0367-326x(00) 00270-7

32. Qadir A, Ali A, Arif M, et al. Solvent extraction and GC-MS analysis of sesame seeds for determination of bioactive antioxidant fatty acid/fatty oil components. J Drugs Res. 2018;68(6):344-348. doi:10. 1055/s-0043-123466

33. Voravuthikunchai SP, Sririrak T, Limsuwan S, Supawita T, lida T, Hond T. Inhibitory effect of active compounds from Punica granatum pericarp on verocytotoxin production by enterohemorrhagic Escherichia coli 0157:H7. J Health Sci. 2005;51:590-596. https://www.jstage.jst. go.jp/article/jhs/51/5/51_5_590/_pdf

34. Naz S, Siddiqi R, Ahmad S, Rasool SA, Sayeed SA. Antibacterial activity directed isolation of compounds from Punica granatum. J Food Sci. 2007;72(9):341-345. doi:10.1111/j.1750-3841.2007.00533.x

35. Nuamsetti T, Dechayuenyong $P$, Tantipailbulvut $S$. Antibacterial activity of pomegranate fruit peels and arils. Science Asia. 2012;38:319-322. doi:10.2306/scienceasia1513-1874.2012.38.319

36. Negi PS, Jayaprakasha GK. Antioxidant and antibacterial activities of Punica granatum peel extracts. J Food Sci. 2003;68:1473-1477. doi:10.1111/j.1365-2621.2003.tb09669.x 